\title{
ШЛЯХИ ОПТИМІЗАЦІї ВИКЛАДАННЯ ДИСЦИПЛІНИ “НЕВІДКЛАДНА МЕДИЧНА ДОПОМОГА” ДЛЯ МОЛОДШИХ СПЕЦІАЛІСТІВ 3 МЕДИЧНОЮ ОСВІТОЮ
}

\author{
С. В. Канівець, О. Є. Денисик \\ КЗ “Криворізьке училище підвищення кваліфікації та перепідготовки молодших медичних \\ і фармацевтичних спеціалістів" дОР”
WAYS OF TEACHING OPTIMIZATION OF DISCIPLINE “MEDICAL EMERGENCY” FOR JUNIOR SPECIALISTS WITH MEDICAL EDUCATION

\author{
S. V. Kanivets, O. Ye. Denysyk \\ Kryvyi Rih School of Training and Retraining of Junior Medical Specialists and Pharmacists
}

\begin{abstract}
У статті узагальнено досвід роботи педагогічного колективу училища з оптимізації викладання дисципліни “Невідкладна медична допомога” для молодших спеціалістів з медичною освітою. Визначені основні компоненти освітнього процесу та заходи з їх удосконалення, що були здійснені у закладі з метою оптимізації викладання дисципліни “Невідкладна медична допомога”. Об’єднання циклів підвищення кваліфікації у групи залежно від вірогідності виникнення потреби у наданні екстреної медичної допомоги на робочому місці дозволило диференційовано підійти до розподілу обсягу навчальних годин, що відводяться на вивчення дисципліни. Пріоритетність практичного навчання у сучасній професійній підготовці фахівців визначила збільшення частки практичних занять. Відпрацьована 5-етапна форма навчання з цієї дисципліни, заходи з формування висококваліфікованого викладацького складу та створення відповідної матеріально-технічної бази дозволили підвищити якість післядипломного навчання з дисципліни.
\end{abstract}

This article adduces the experience of the teaching staff of Kryvyi Rih school training and retraining of junior medical specialists in an optimization teaching the discipline emergency medical care for junior specialists with medical education. There were defined the main components of the educational process and steps of their improvement, which were committed in the institution in order to optimize of teaching of discipline "Medical emergency". Combining cycles of training in groups depending on probability appearance of the need to provide emergency medical care in the workplace allowed differentiating approach to the distribution of teaching hours allocated to the subjects. The priority of practical training in the modern professional preparation of specialists determined the increase in the share of practical lessons. It was fulfilled 5-steps model of teaching the discipline actions on forming a highly qualified teaching staff and creation of appropriate material and technical resources enabled increasing efficiency postgraduate training courses.

Вступ. Теперішній час характеризується збільшенням показників негативних наслідків надзвичайних ситуацій різних типів на життя і здоров’я населення планети. Це робить актуальним своєчасне та кваліфіковане надання екстреної медичної допомоги (ЕМД). В останній час негативні події присутні в значній кількості і на території України, що призводить до значних втрат населення. Порівняно з розвиненими країнами українські показники смертності населення працездатного віку внаслідок нещасних випадків, травм та отруєнь $є$ вищими більше ніж у 10 разів [1]. При цьому аналіз світових показників негативних наслідків травмування свідчить про тенденцію стійкого їх зростання [2].

(ㄷ. С. В. Канівець, О. Є. Денисик
Надання якісної ЕМД вимагає від медичних працівників добре сформованої компетенції прийняття ефективного рішення в екстремальних умовах, спрямованого на збереження життя людини $[3,4]$. Тому якісне викладання дисципліни “Невідкладна медична допомога” (НМД) виступає вагомою складовою усієї системи додипломної та післядипломної підготовки молодших спеціалістів з медичною освітою.

Законодавчими актами [5-7] визначено стратегічний напрям формування та розвитку системи надання ЕМД в Україні. Мова йдеться, в першу чергу, про “Медицину катастроф” як предметну галузь, яку повинні опанувати медичні працівники незалежно від фаху з метою організації та вчасного 
надання ЕМД населенню у разі виникнення надзвичайних ситуацій різного характеру.

Основна частина. Метою даного дослідження було вивчення впливу заходів з оптимізації викладання дисципліни НМД на результативність післядипломного навчання молодших спеціалістів 3 медичною освітою.

Як відомо, на результативність освітнього процесу впливає якість організації усіх компонентів, з яких він складається: організаційного, кадрового, навчально-методичного, матеріально-технічного тощо.

Розуміння цього спонукало педагогічний колектив училища розпочати у 2008 році поетапну роботу в напрямку підвищення якості післядипломної підготовки молодших медичних спеціалістів з питань ЕНМД. В училищі протягом останніх восьми років був здійснений певний ряд заходів з удосконалення викладання НМД (табл. 1).

Таблиця 1. Основні заходи з удосконалення компонентів освітнього процесу з НМД в училищі

\begin{tabular}{|c|c|}
\hline $\begin{array}{c}\text { Компоненти } \\
\text { освітнього процесу }\end{array}$ & Заходи з удосконалення \\
\hline Організаційний & $\begin{array}{ll}\text { - } & \text { перегляд навчальних планів з урахуванням контингенту слухачів та форми навчан- } \\
\text { ня; } \\
\text { - } \\
\text { перерозподіл навчальних годин у межах дисципліни в бік збільшення обсягу часу } \\
\text { практичних занять; } \\
\text { - }\end{array}$ \\
\hline $\begin{array}{l}\text { Навчально- } \\
\text { методичний }\end{array}$ & $\begin{array}{l}\text { - } \\
\text { - } \text { створення навчально-методичного комплексу дисципліни; } \\
\text { - } \text { створення банку тестових завдань для комп’ютерного контролю знань слухачів тощо }\end{array}$ \\
\hline Кадровий & $\begin{array}{ll}\text { - } & \text { післядипломне навчання викладачів НМД; } \\
\text { - } & \text { участь викладачів у роботі лікарських наукових товариств; } \\
\text { - } & \text { участь викладачів у різного рівня конференціях, семінарах, тренінгах тощо; } \\
\text { - } & \text { робота викладачів над індивідуальною методичною проблемою тощо } \\
\end{array}$ \\
\hline $\begin{array}{l}\text { Матеріально- } \\
\text { технічний }\end{array}$ & 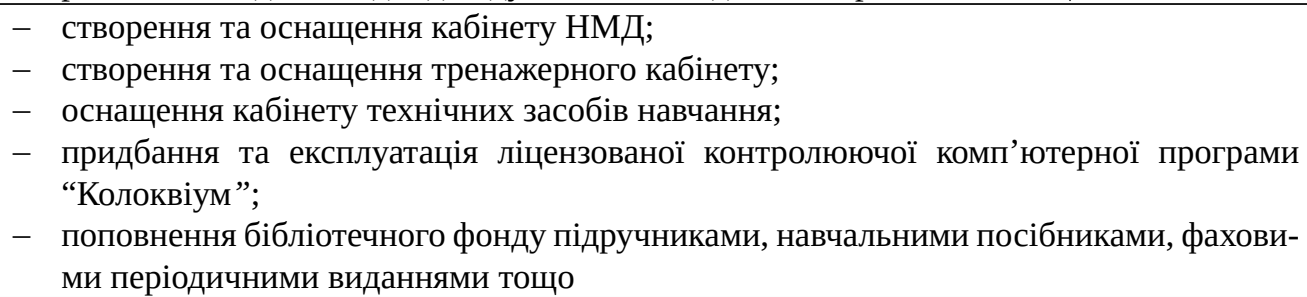 \\
\hline
\end{tabular}

Організаційний компонент включає в себе, в першу чергу, нормативне забезпечення навчального процесу, до складу якого входять навчальні плани та навчальні програми. 32008 р. в училищі був розпочатий перегляд навчальних планів усіх циклів з урахуванням вимог нормативних документів Міністерства охорони здоров’я України, закордонного та вітчизняного досвідів у викладанні НМД, а також 35-річного досвіду роботи педагогічного колективу училища.

У навчальних планах 1990-2000 рр., незалежно від фаху молодших спеціалістів з медичною освітою, обсяг навчальних годин, що відводилися на вивчення НМД, складав 16 навчальних годин (теорія 10 год, практика 6 год).

При розробці нових навчальних планів та розподілі навчальних годин між дисциплінами враховувався контингент слухачів (табл. 2).

Умовно усі навчальні цикли, що проводяться в училищі, були об’єднані в 3 групи залежно від вірогідності виникнення потреби у наданні ЕМД на робочому місці. До першої групи були віднесені лаборанти (фельдшери-лаборанти) клінічних та інших лабораторій, працівники санітарної служби, зубні техніки, медичні статистики, медичні сестри з лікувального харчування, тобто ті фахівці, які не стикаються з потребою надання ЕМД пацієнтам щоденно. Для слухачів цих циклів обсяг навчальних годин залишено незмінним - 16 год.

До наступної групи потрапили акушерки, фельдшери та медичні сестри, за винятком медичних сестер загальної практики - сімейної медицини та фельдшерів (медсестер) цехових лікарських дільниць, здоровпунктів. Для них обсяг навчальних годин з НМД склав 24 год. Дана група об’єднує основний контингент училища.

32-годинний обсяг навчальних годин визначений для третьої групи - медичних сестер загальної практики - сімейної медицини та фельдшерів (медсестер) цехових лікарських дільниць, здоровпунктів. 
Таблиця 2. Розподіл навчальних годин, що відводяться на викладання НМД залежно від контингенту слухачів

\begin{tabular}{|c|c|c|}
\hline \multirow{2}{*}{ Контингент слухачів } & \multicolumn{2}{|c|}{ Обсяг навчальних годин } \\
\hline & до 2008 р. & після 2008 р. \\
\hline $\begin{array}{l}\text { Зубні техніки, медсестри з лікувального харчування, } \\
\text { медстатистики установ ЛПУ, лаборанти }\end{array}$ & \multirow{3}{*}{16} & 16 \\
\hline $\begin{array}{l}\text { Медичні сестри, акушерки, фельдшери (крім фельдшерів } 3 \\
\text { медицини невідкладних станів) }\end{array}$ & & 24 \\
\hline $\begin{array}{l}\text { Медичні сестри загальної практики - сімейної медицини, } \\
\text { фельдшери (медсестри) цехових лікарських дільниць, } \\
\text { здоровпунктів }\end{array}$ & & 32 \\
\hline
\end{tabular}

Так, у 2015-2016 н. р. в училищі організовано та проведено навчальні цикли удосконалення та спеціалізації з 59 найменувань (згідно 3 наказом МОЗ України від 07.09.1995 р. № 198 [8]), 3 них викладання НМД за 16-годинною програмою здійснювалося лише на 12 (20,3%) циклах, для більшості циклів (69,5 \%) викладання дисципліни здійснювалося за 24-годинною програмою (рис. 1). Навчальні плани циклів для фельдшерів 3 медицини невідкладних станів не передбачають вивчення НМД.

Зміни навчальних планів стосувались не тільки збільшення навчальних годин, що відводяться на вивчення НМД, а й їх перерозподілу між теоретичними та практичними заняттями в бік збільшення частки останніх (табл. 3), що є пріоритетним у сучасній професійній підготовці фахівців.

Таким чином, практичне навчання займає в середньому 66 \% навчального часу дисципліни, що дозволяє приділяти основну увагу відпрацюванню практичних навичок та вмінь. Практичний компо- нент навчальної програми передбачає формування у слухачів як мінімум 36 практичних навичок. Так, на відпрацювання однієї практичної навички кожним слухачем витрачається 20-27,5 хв (табл. 4).

Світовий досвід свідчить про те, що найбільш ефективною $€$ комбінована форма навчання в організації занять з НМД, в якій послідовно відпрацьовуються 5 етапів, що замикаються в коло [4]. В училищі також відпрацьована 5-етапна форма навчання з цієї дисципліни, але вона має свої відмінності (табл. 5).

Зміст теоретичних занять спрямований на оновлення та вдосконалення базових знань 3 дисципліни. На практичних заняттях з використанням різних форм та методів роботи відбувається індивідуальне (групове) оволодіння практичними навичками, їх вдосконалення, формування вмінь надавати екстрену та невідкладну медичну допомогу в стандартних та нестандартних ситуаціях. Завершується вивчення дисципліни обов'язковим складанням двоступеневого заліку, що включає комп’ютерне тестування та де-

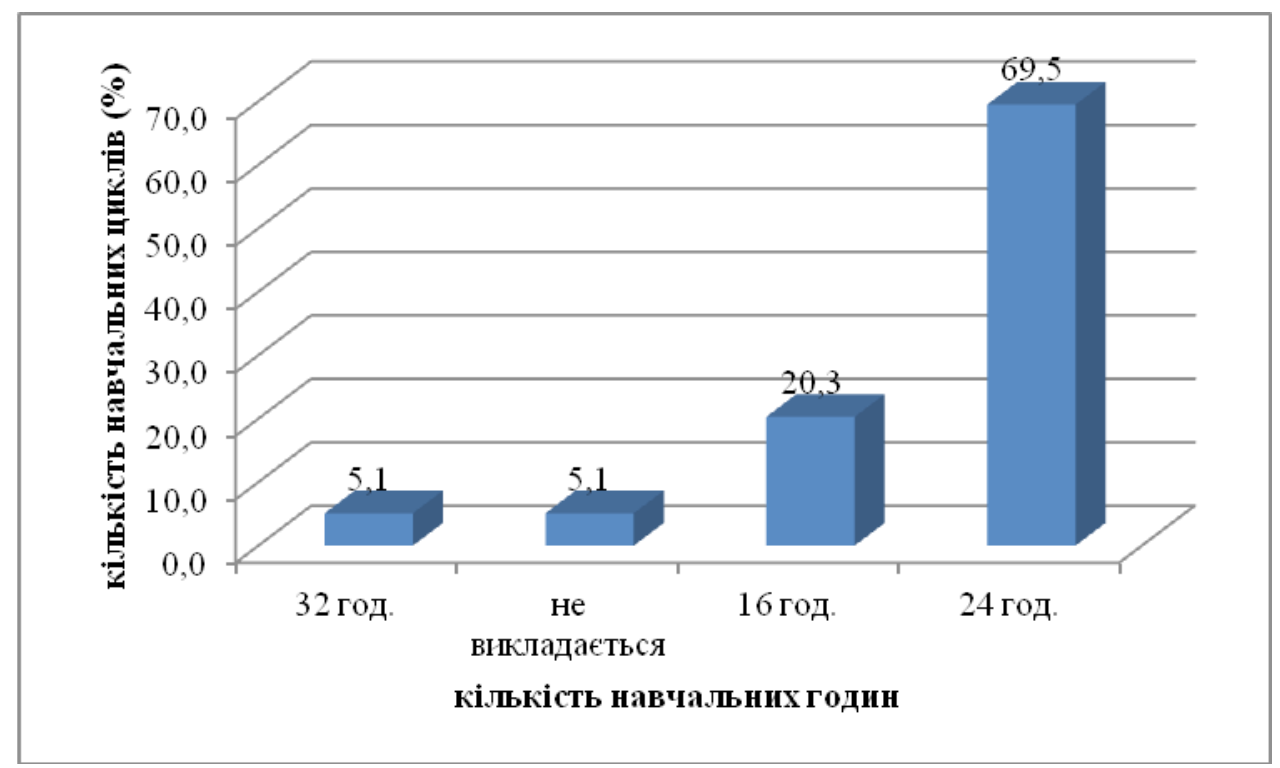

Рис. 1. Розподіл циклів підвищення кваліфікації за обсягом навчальних годин дисципліни “Невідкладна медична допомога” у 2015-2016 н. р. 
Таблиця 3. Розподіл навчальних годин між теоретичними та практичними заняттями

\begin{tabular}{|c|c|c|c|c|}
\hline \multirow{3}{*}{$\begin{array}{l}\text { Загальна кількість } \\
\text { навчальних годин }\end{array}$} & \multicolumn{4}{|c|}{ Навчальні години } \\
\hline & \multicolumn{2}{|c|}{ теоретичні заняття } & \multicolumn{2}{|c|}{ практичні заняття } \\
\hline & кількість & $\%$ & кількість & $\%$ \\
\hline 16 & 6 & 37,5 & 10 & 62,5 \\
\hline 24 & 8 & 25,0 & 16 & 75,0 \\
\hline 32 & 10 & 31,3 & 22 & 68,7 \\
\hline Середнє & & 31,3 & & 68,7 \\
\hline
\end{tabular}

Таблиця 4. Кількісні показники навчальних планів дисципліни НМД

\begin{tabular}{|c|c|c|c|}
\hline $\begin{array}{c}\text { Тривалість циклу } \\
\text { підвищення кваліфікації } \\
\text { (год) }\end{array}$ & $\begin{array}{c}\text { Тривалість мікроциклу } \\
\text { НМД (год/\%) }\end{array}$ & $\begin{array}{c}\text { Кількість практичних } \\
\text { навичок }\end{array}$ & $\begin{array}{c}\text { Середня тривалість } \\
\text { відпрацювання } \\
1 \text { практичної навички, хв }\end{array}$ \\
\hline 144 & $24 / 16,7$ & 36 & 20 \\
\hline 432 & $32 / 7,4$ & 36 & 27,5 \\
\hline
\end{tabular}

Таблиця 5. Етапність навчання з НМД

\begin{tabular}{|l|l|}
\hline \multicolumn{1}{|c|}{ Світовий досвід } & \multicolumn{1}{|c|}{ КЗ “КУПК” ДОР” } \\
\hline Теоретична підготовка & Теоретична підготовка \\
\hline $\begin{array}{l}\text { Індивідуальна практика окремих практичних } \\
\text { навичок }\end{array}$ & Індивідуальне відпрацювання практичних навичок \\
\hline Персональний комп’ютерний тренінг & \\
\hline Відпрацювання практичних навичок у команді & Групове відпрацювання практичних навичок та вмінь \\
\hline Щоденна практика у галузі & Рішення ситуаційних задач тощо \\
\hline \multicolumn{2}{|c|}{} \\
\hline
\end{tabular}

монстрацію слухачами практичних навичок і вмінь. Комп’ютерне тестування слухачів здійснюється за допомогою ліцензованої програми “Колоквіум”.

Навчально-методичний компонент передбачає, в першу чергу, забезпеченість навчальних занять необхідними навчально-методичними матеріалами. Викладачами розроблені робочі програми з НМД та створені навчально-методичні комплекси для 16-ти, 24-х та 32-х навчальних годин. Банк тестових завдань для підсумкового комп’ютерного контролю знань з екстреної та невідкладної медичної допомоги налічує 375 тестів.

Для проведення навчальних занять з НМД в училищі створено й оснащено профільний навчальний кабінет та тренажерний кабінет, що забезпечують можливість одночасного проведення практичних занять у двох навчальних групах. Матеріально-технічне забезпечення кабінетів відповідає вимогам наказу МОЗ України від 18.03.2005 р. № 120 [9].

Підвищення якості навчального процесу не можливе без наявності висококваліфікованих викладачів, які володіють найсучаснішими знаннями з дисципліни. До викладання НМД залучаються викладачі, які мають значний досвід роботи у практичній охороні здоров'я. Так, в середньому медичний стаж викладачів складає 19 років, а педагогічний - 18 років. Дисципліну викладають викладачі, які мають кваліфікаційні категорії “спеціаліст першої категорії” (75 \%) і “спеціаліст вищої категорії” та педагогічне звання “викладач-методист” (25 \%).

У реалізації кадрової компоненти забезпечення якості освіти велика увага приділяється зростанню фахової майстерності викладацького складу закладу через організацію підвищення кваліфікації на різноманітних курсах, тренінгах, семінарах тощо. Так, за 2009-2015 pр. усі п’ять викладачів дисципліни НМД пройшли навчання на 13 різноманітних циклах у 6 навчальних закладах післядипломної освіти. Таким чином, періодичність навчання викладачів з різних питань НМД становить 1 раз на 2-3 роки, що забезпечує якісне оволодіння ними сучасними знаннями та вміннями.

Крім організації післядипломного навчання викладачів, велика увага приділяється їх участі у конгресах, науково-практичних конференціях, тренінгах тощо. Протягом 2011-2015 рр. викладачі училища взяли участь у Всеукраїнській науково-практичній конференції з міжнародною участю 
“Екстрена медична допомога. Європейські стандарти - 2010” (2011 р.), науково-практичній конференції “Актуальні питання підготовки кадрів з екстреної медичної допомоги і медицини катастроф” (2011 р.), Всеукраїнському конгресі з міжнародною участю “Екстрена медична допомога: організаційно-методичні та клінічні аспекти. Досвід, проблеми та перспективи розвитку” (2013 р.), інтерактивному тренінг-курсі з військово-польової/тактичної медицини “Ізраїльський досвід в наданні невідкладної догоспітальної медичної допомоги в бойових умовах” (2015 р.), Всеукраїнському семінарі-тренінгу
“Основи оперативно-тактичного догляду за пораненими” та “Розширений догоспітальний догляд при травмі” (2015 р.).

В якості об’єктивного показника навчальних досягнень слухачів у вивченні НМД в закладі використовуються результати комп’ютерного тестування, що є обов'язковим для кожного слухача i являє собою одну зі складових частин заліку з дисципліни. Таке тестування запроваджено в училищі починаючи з 2011 р. Аналіз чотирирічних результатів свідчить про позитивну динаміку навчальних досягнень слухачів з НМД (табл. 6).

Таблиця 6. Динаміка якісних показників комп’ютерного тестування слухачів з НМД за 2012-2016 pp.

\begin{tabular}{|l|c|c|c|c|}
\hline \multicolumn{1}{|c|}{ Показники } & $2012 / 13$ н. p. & $2013 / 14$ н. p. & $2014 / 15$ н. p. & $2015 / 16$ н. p. \\
\hline Кількість протестованих слухачів & 1323 & 1479 & 1390 & 1242 \\
\hline Середній бал & 4,3 & 4,5 & 4,8 & 4,7 \\
\hline \% правильних відповідей & 82,9 & 87,1 & 91,1 & 90,0 \\
\hline Якість знань слухачів & 96,5 & 96,8 & 96,0 & 98,0 \\
\hline
\end{tabular}

Висновок. Таким чином, на сьогодні в училищі створено дієву систему ефективної післядипломної підготовки молодших медичних спеціалістів 3 ЕНМД. Розробка та реалізація основних заходів

\section{Список літератури}

1. Досвід та перспективи підвищення якості надання екстреної медичної допомоги шляхом підготовки персоналу / П. В. Римаренко, Т. С. Лисиця, В. О. Крилюк, А. Б. Чернов // Екстрена медична допомога. Європейські стандарти - 2010 : матеріали Всеукр. наук.-практ. конф. 3 міжнар. участю (31 бер. - 1 квіт. 2011). - К., 2011. - С. 114-115.

2. Йовенко И. А. Обзор европейского руководства “Управление кровотечением и коагулопатией вследствие тяжелой травмы”(2013) / И. А. Йовенко // Острые и неотложные состояния в практике врача. - 2014. № 6. - С. 5-18.

3. Камбалов М. Н. О необходимости совершенствования организации преподавания дисциплины “Медицина экстремальных ситуаций” при подготовке офицеров медицинской службы запаса / М. Н. Камбалов, С. А. Анашкина // Военная медицина. - 2008. - № 1. C. $15-16$.

4. Етапи підготовки з надання екстреної медичної допомоги фахівців з медичною освітою / Д. Д. Дячук, з удосконалення компонентів освітнього процесу дозволила підвищити якість навчання з НМД молодших спеціалістів з медичною освітою.

П. В. Римаренко, І. В. Мельник [та ін.] // Екстрена медична допомога. Європейські стандарти - 2010 : матеріали Всеукр. наук.-практ. конф. $з$ міжнар. участю (31 бер. 1 квіт. 2011). - К., 2011. - С. 51-53.

5. Про екстрену медичну допомогу : Закон України від 05.07.2012 р. № 5081-VI.

6. Про удосконалення підготовки та підвищення кваліфікації медичних працівників з надання екстреної та невідкладної медичної допомоги : наказ МОЗ України від 28.04.2009 р. № 283.

7. Про затвердження та впровадження медико-технологічних документів зі стандартизації екстреної медичної допомоги : наказ МОЗ України від 15.01.2014 р. № 34.

8. Про підвищення кваліфікації молодших спеціалістів 3 медичною та фармацевтичною освітою : наказ МОЗ України від 07.09.1993 р. № 198.

9. Про організацію навчання медичних і немедичних працівників 3 надання медичної допомоги в екстрених ситуаціях : наказ МОЗ України від 18.03.2005 р. № 120. 